\title{
Block grant opposed for NIH clinical centre
}

Washington. A leading congressional figure responsible for handling the budget of the US National Institutes of Health (NIH) said last week that he will not support President Bill Clinton's request that all the funding for the new \$310-million Clinical Research Center (CRC) should be taken from the 1997 budget.

John Porter (Republican, Illinois), chairman of the House of Representatives appropriations subcommittee that oversees NIH spending, said that, in the absence of an unexpectedly large - and unlikely budget allocation to his committee, he plans to propose that the money for the centre be distributed over three or four years.

Porter said that he would prefer the budget for the fiscal year 1997, which begins on 1 October, to fund merely "one of the four years" for the centre. This would then allow his subcommittee to fund extramural research "at an increased level of, say, 6 or 6.5 per cent [above the 1996 level]" in 1997. The current budget proposal allows for an increase of only 2.6 per cent in extramural research grant funding.

Porter, speaking after a hearing of the

\section{Chernobyl damage 'underestimated'}

Munich \& Tokyo. The medical consequences of the Chernobyl disaster have been seriously underestimated, according to Alexei Yablokov, head of the Centre for Russian Environment Policy, who chaired a meeting in Moscow last week attended by 45 non-governmental organizations.

Yablokov criticized Western scientists for ignoring data gathered by scientists from the new independent states (NIS) of the former Soviet Union. So far there is only a consensus on an increase in thyroid cancer in children, but NIS researchers presented extensive data on alterations in biological parameters at the cellular, biochemical and immunological levels in populations exposed to low levels of radiation for prolonged periods. They also presented epidemiological studies reporting increased incidences of a range of ailments.

Such results are regarded with caution by Western scientists because of the lack of controls and uncertain diagnoses. John Harrison, for example, deputy director of the UK National Radiological Protection Board, who has worked with the World Health Organization (WHO) programme to improve methods of collecting data in the affected areas, says one problem with the NIS data is the lack of a reliable registry of mortality and morbidity in the affected states (Belarus, Russia and Ukraine).

But according to Yablokov, who was science adviser to Boris Yeltsin, the health effects of Chernobyl will plague its victims subcommittee on the NIH's budget request, argued that, because extramural research needs "momentum", it would suffer without a larger increase than the president proposed. "If you squeeze it down in the way that the [Clinton] administration suggests, I think you're going to lose a great deal more than just what the numbers might suggest. You are going to lose people. You are going to lose commitment."

The Office of Management and Budget (OMB) maintains that allocating all of the money in a single funding for CRC. year will be more

efficient. Lawrence Haas, an spokesman for OMB, says that it also avoids the risk that Congress will cut off funds in later years, "which would leave you with a half-built building".

But Porter argues that there is virtually

"for generations, practically forever". Low levels of radiation have been shown to have a much greater effect than predicted from the accepted view that dose-effect relationships are linear, he claims.

Nevertheless, there is broad agreement on the need for continued monitoring of the health of those affected by radiation. Because of the long latency of most solid tumours, says Harrison, no firm conclusions about the health consequences of the accident can be made for at least ten years.

But it is not clear how long international funding is likely to continue. In addition to bilateral health programmes, in particular the Japanese Sasakawa Memorial Health Foundation, which provided more than ECU40 million (US\$50 million) to set up five medical diagnostic centres within the affected areas, the European Commission (EC) and the World Health Organization (WHO) have been the major sponsors of international health programmes, which are now coming to an end.

Nearly all of the WHO money was donated by Japan, and the organization has not yet succeeded in persuading any country to finance a continuation of the programme. The EC will continue supporting projects within the fourth Framework programme, which runs until 1999, but these will now have to compete for the general pool of money set aside for research involving NIS partners, the socalled INCO programme.

Alison Abbott \& Stephen Barker no risk of such an outcome. "The potential for finishing [the construction work] is very good. It's very unlikely we would back away from that commitment in future years".

At the hearing last week, Porter quizzed Harold Varmus, the director of NIH, on the impact of compensatory cuts in other NIH programmes in the Clinton administration's 1997 budget proposal, released in March. About two-thirds of the $\$ 467$ million in new money requested for the NIH - a 3.9 per cent increase over 1996 - would be used to finance the new clinical facility. Most of the remainder would go to extramural research grants. But funding for intramural research would fall by 0.2 per cent, and multi-year extramural grant recipients would fall from four to two per cent in their routine increases to cover the costs of inflation. ('Biomedical inflation' is now 3.7 per cent).

The CRC is a planned 250-bed addition to the current NIH Clinical Center, a 1953 building that would be partially converted to other uses. Completion of the extension is expected early next century. Varmus argued that money being requested for the new facility is an "add-on", not a substitute for support for external scientists.

Varmus also said that the reduction in inflationary increases for multi-year grant recipients would not impose a significant burden. "This is a very tight budgetary environment. And the money [for the $\mathrm{CRC}$ ] is being requested in response to a clear need," he said.

But Francine Little, director of the NIH's Office of Financial Management, told scientists at a separate meeting last week that the A111 had initially proposed that the $\mathrm{CRC}$ be funded in \$90million installments over four years. The Clinton administration modified the request to a single allotment.

This proposal has caused murmuring among extramural researchers and their allies in Congress. It leaves "only enough money for about a 1.6 per cent increase for everything else, particularly research grants," says Jerold Roschwalb, a lobbyist for the National Association of State Universities and Land-Grant Colleges, which represents major public research universities in every state.

Porter, an ardent advocate for biomedical research, appears to have lost none of his enthusiasm for the NIH since last year, when he was primarily responsible for securing a 5.8 per cent budget increase for the NIH in 1996 at a time when other federal agencies were limping along on temporary spending measures or being forced to shut down due to a budget impasse. "I just can't think of any part of government that is doing a better job," he told Varmus. "We just want to do everything we can to provide to you the kind of tools that you need including the clinical centre."

Meredith Wadman 